\title{
NOSSO AUGUSTO DOS ANJOS
}

\section{Otto Maria Carpeaux}

Ao amigo e editor Carlos Ribeiro não preciso desejar sucesso de sua Edição Comemorativa do $E u$, bem cuidada e com prefácio do meu prezado Francisco de Assis Barbosa. É a 29aa edição do livro. Quer dizer: o sucesso de venda está garantido. Só é desejável que essa primeira edição realmente utilizável da obra também se torne bom negócio para a literatura brasileira.

É conhecida a acidentada "fortuna" do autor e de sua obra. Depois da primeira fase, devida à soberbia e ignorância dos pseudo-príncipes parnasianos, veio o imenso sucesso popular, só comparável ao dos poetas românticos. Mas estes conquistaram a alma do povo, apelando para o que há nele de generoso e infantil, verbalista e anedótico - em suma, um sucesso justificado pela substância dessa poesia. O sucesso do Eu foi devido a um equívoco: a expressões grotescas, conceitos pseudocientíficos e pseudoreligiosos e à forma parnasiana, facilmente declamável - em suma, àquilo que não tem nada que ver com a substância dessa poesia. Por isso, o modernismo a condenou. Essa fase também foi superada. E Augusto dos Anjos chegou a ser tão altamente apreciado pelos "progressistas" literários que lhe prestaram a suposta suprema homenagem de submeter-lhe a poesia à análise estilística.

Aconteceu o que se podia prever: em vez de revelar a originalidade do poeta, descobriram-se as influências e as "influências", concluindo-se: falta de originalidade.

Influências? A de Baudelaire é manifesta. Por quê? Porque Augusto dos Anjos compreendeu realmente Baudelaire, numa época em que a crítica brasileira o considerava como o Álvares de Azevedo francês e em que o imitavam os poetas "satanistas". Cesário Verde? Nem sei com certeza se Augusto dos Anjos o tinha lido; e não encontro a mui afirmada semelhança. Cruz e Souza? Aceito apostas com quem me apresentar um único verso de Cruz e Souza que poderia ser atribuído, erroneamente, a Augusto dos Anjos e vice-versa. Se existe "influência", é a da chamada "poesia científica" de Isidoro Martins Júnior e outros, exploração pseudopoética das lições dos mestres da Escola do Recife. Mas a imensa diferença de nível entre essa "poesia científica" e a de Augusto dos Anjos - e em poesia, nível é tudo - demonstra que as influências não significam nada. 
A caça às influências é uma das formas, depois de Benedetto Croce já condenadas, de explicação causal das expressões artísticas.

No caso de Augusto dos Anjos, todas as interpretações pecam pelo causalismo, emprego ilegítimo do conceito naturalístico "causa-efeito" num terreno em que, por definição, não existe determinismo. Num causalismo ilícito baseia-se a própria crítica estilística que acredita em efeito fatal, inevitável e até inconsciente (o estilo do autor) de uma causa não definida e não definível (a mentalidade do autor). Causalística é a atribuição de particularidades essenciais de um autor à causa "influências". Causalística é a explicação da arte de Augusto dos Anjos pela tuberculose; se fosse assim, todos os poetas tuberculosos deveriam ter certas qualidades comuns. Mas, quem nega a tuberculose de Augusto dos Anjos, apenas pretende substituir aquela hipótese pela de outra doença qualquer; que ainda menos interessa, pois uma crítica séria não pode admitir, como critério, a classificação - poetas tuberculosos, poetas sifilíticos, poetas diabéticos, poetas que sofrem de doença de Parkinson. etc. Causa-lídica é a interpretação da poesia de Augusto dos Anjos pela angústia, pois qual foi a cansa da angústia? A explicação do pessimismo do poeta pela decadência econômica de rua classe, dos senhores de engenho, é de um determinismo econômico primitivo que seria inadmissível entre marxistas realmente formados em marxismo.

No fundo, todas essas explicações pretendem explicar o pessimismo de Augusto dos Anjos. Nisso tem razão meu amigo Ledo Ivo, que deixa porém de ter razão quando começa a refutar, em vez das explicações de pessimismo, o próprio pessimismo. Augusto dos Anjos foi pessimista? É tese discutível. Supondo que foi: o otimismo dos modernistas de 1922, que por isso mesmo desprezaram Augusto dos Anjos, é igualmente ou mais discutível. Sófocles foi pessimista? Shakespeare, o autor do Rei Lear, foi pessimista? Nem diria tanto. Foram poetas trágicos. Quem os chama de pessimistas, não lhes percebe a tragicidade, agarrando-se a termos de mitologia grega ou de mentalidade barroca, produtos da época e sem significação permanente. Augusto dos Anjos também é poeta trágico. É preciso percebê-lo através e atrás dos seus termos científicos e pseudo-científicos, produtos de sua época, contingentes, sem relação necessária com a substância de sua poesia.

Não temos direito de ignorar esses "defeitos" da poesia de Augusto dos Anjos. São defeitos. São sinais de mau gosto de sua época e de seu ambiente literário. São sinais do seu "mau gosto. Mas basear neles a crítica de sua poesia - como parece fazer meu amigo Antonio Candido - significaria substituir a defunta "crítica das belezas" de épocas classicistas, o destaque dado a expressões ou versos excepcionalmente belos, anto- 
lógicos, para provar a alta categoria de um poeta, significa, digo, substituir essa "crítica das belezas" por uma crítica das fealdades para provar a categoria inferior do poeta. É fragmentação de poesia em vez de unificação do pensamento e da expressão poética.

Essa "unificação", que a crítica literária italiana considera como a fase definitiva da interpretação de uma obra poética. Explicação, não: mas demonstração de magia verbal pela qual a poesia transfigura o mundo. Se eu escrevesse em italiano ou em inglês, faria aqui o ponto. Mas no país de Bilac, Coelho Neto e Ruy Barbosa, o adjetivo pode ter sentido diferente do que num I. A. Richards ou num Giacomo Devoto. "Verbal", naquela definição, é elemento da arte de carregar de sentido, de meaning, as palavras de uma frase, de um verso, de tal modo que nenhuma sílaba fica sem significação emocional. Essa arte tem um limite certo: os nomes próprios. Ainda é possível, talvez, que tenham significação emocional para quem esteja ligado a esses nomes próprios por associações. Quem nasceu ou viveu no Recife, pode ter associações ligadas à Ponte Buarque de Macedo, associações tristes ou alegres ou de desespero ou de esperança baseados em momentos experimentados naquela ponte. Para os muitos que, como eu, nunca estiveram no Recife, é um nome próprio que não nos diz nada.

Mas lendo o verso de Augusto dos Anjos - "Recife. Ponte Buarque de Macedo", um verso composto só de nomes próprios, emocionalmente indiferentes, aquele ponto, aquela cesura atrás da palavra "Recife" basta para nos dar um frisson, para adivinhar algo de fundamente significativo atrás da ponte. É um verso cheio de meaning como só um grande poeta podia escrevê-lo.

In: Leitura, $\mathrm{n}^{\circ}$ 74, RJ, ago. 1963. 